\title{
Book Review: Collaborative
}

Learning Communities in

Middle School Literacy

Education: Increasing Student

Engagement With Authentic

Literacy

Excelsior: Leadership in

Teaching and Learning 2021, Vol. 13(3), 274-277

(C) The Author 2021

CC-BY 4.0 International

Reprints and permissions:

surface.syr.edu/excelsior

https://doi.org/10.14305/in.1

9440413.2021.13.3.06

nyacte.org

MaryAnn Dunn ${ }^{1}$

Malavasic, J. (2020). Collaborative learning communities in middle school literacy education: Increasing student engagement with authentic literacy (92 pp.). Routledge. ISBN: 9780367727154

\section{Keywords:}

adolescent literacy, teacher preparation, collaborative learning community, building supportive relationships, engagement

Creating a collaborative learning environment where adolescents feel valued as co-constructors of knowledge can improve literacy learning outcomes for youth. This concept is the basis for the book, Collaborative Learning Communities in Middle School Literacy Education: Increasing Student Engagement With Authentic Literacy, by Jolene T. Malavasic (2020). She describes a framework for engaging middle schoolers in an after-school literacy program as part of a graduate practicum course. The program is a powerful model for teachers, teacher educators, and administrators not only regarding literacy instruction but also for building supportive relationships among teachers, students, and peers. Interwoven throughout the book's seven chapters are descriptions of a graduate teacher preparation course, an afterschool literacy program for middle school students, and theoretical foundations for the creation of both the graduate course and literacy program. While reading this book, as a high school special educator and literacy graduate student, my internal dialogue was afire with connections to adolescents, relationship building, collaborative learning, and the literacy strategies described by Malavasic. The graduate course and literacy program are intertwined and intentionally rooted in the

\footnotetext{
${ }^{1}$ University at Albany, State University of New York Corresponding Author:

Mary Ann Dunn, University at Albany, State University of New York, 1400 Washington Avenue, Albany, NY, 12222

Email: mdunn4@albany.edu
} 
theoretical foundations of cognitive distribution, identity, knowledge-building and funds of knowledge.

\section{Graduate Course Design}

The graduate course is part of a practicum for a master's degree in literacy at the secondary level at the University at Albany, State University of New York. In the practicum course, graduate students participate in an after-school literacy workshop two times per week at a neighboring middle school, as well as attend a seminar style class after each literacy workshop session. Malavasic leads us through the entire process of the graduate class including sample assignments and responses from written reflections. Vital to the learning of the graduate students are video and audio analyses which offer structured opportunities for feedback and reflection. The graduate students create learning communities for middle school students, and they participate in a learning community with their peers in the course. Additionally, they are gaining specific experiences to prepare them for successful leadership as a reading specialist and/or literacy coach.

\section{Literacy Workshop Design}

From the descriptions and examples included in Collaborative Learning Communities in Middle School Literacy Education, literacy specialists and classroom teachers can easily incorporate the entirety or components of the literacy workshop in their middle or high schools. The key elements of the literacy workshop include student choice, inquiry-based units (created in a prerequisite course), reading cycles, modeling, discussion, argument writing, and family celebration. In the literacy workshop, the middle school students first chose their preferred inquiry-based unit which determined the groups of two to four middle school students and two graduate students. Before beginning the units of study, the literacy workshop focused on team building and uncovering the knowledge that the adolescents bring to their literacy learning. Then the groups engaged in three reading cycles of relevant texts, each of which included word work on vocabulary key to the text, guided reading, partner notes and discussion, and interactive summary writing. Each cycle occurred over four group sessions. The adolescents used partner notes on the fourth day for a Socratic seminar debate and free write. Teacher think-alouds, modeling, and accountable talk stems assisted the adolescents, and these supports empowered the adolescents to take risks interacting with their groups as they truly engaged in the knowledge units. At the culmination of the entire knowledge unit, the middle school students wrote an argument-based essay and presented their claims and evidence on a digital platform during a family celebration.

\section{Building Relationships and Communities}

Building relationships and creating collaborative learning communities are the two main purposes of both the middle school program and graduate course. The graduate students learned the process of building supportive relationships with students throughout this program from the first day to the celebration at the end. Learning about the middle school students' personal academic histories which informed their literacy identities is a key element of building supportive relationships. Not only did the graduate students build relationships with the middle school students, but the middle schoolers became active participants in the learning process and took ownership of their literacy practices. The graduate students guided the adolescents through the process of engaging in accountable talk through modeling 
on how to use talk stem prompts. By the end of the program, the adolescents were independent with their discussions. One of the teachers shared that "The students were more engaged because they wanted to be engaged. They initiated the engagements and eventually began to lead the discussions." (Malavasic, 2020, p. 54). When teachers dedicate time to build relationships the result is successful learning outcomes. Building relationships and a sense of community are powerful components of an impactful literacy program for adolescents (Santa, 2006). Equally important, the graduate students created a supportive learning environment for themselves as they learned how to provide useful feedback to each other and developed strategies to create a supportive learning community with their peers as literacy coaches and specialists.

\section{Theoretical Foundation}

Malavasic (2020) states that knowledge-building and cognitive distribution are the theoretical foundations for the graduate program and, thus, the practicum, noting "Given the collaborative nature of this course, the framework of knowledge building goes hand in hand with cognitive distribution" ( $p$. 10). Knowledge building is combined with the features of cognitive distribution through interactions in socio-cultural contexts with artifacts for learning. Though some would argue that cognitive distribution is a solitary act, Mok (2008) proposes that thinking can be distributed in social contexts especially since learning frequently occurs in more collaborative settings. The contexts of learning and funds of knowledge all learners bring have a large impact on their learning and identities (Moll et al., 1992). Educators (teacher educators and secondary teachers) should consider the multifaceted aspects of students' identities and how their interactions with students can shape those identities (Moje et al., 2000). As stated by Malavasic, "Adolescent identities are shaped and continually informed by experiences and interactions." (p. 13). Through these foundations, adolescents are encouraged to bring knowledge, skills, and resourcefulness to social and learning contexts so they can make choices and take the lead for their voices to be heard.

\section{Conclusion}

A classroom teacher or literacy specialist could include every component of the literacy workshop sessions described in the book or create a modified format that works best for their community. The benefits for student engagement and learning far outweigh the efforts of adapting and organizing lessons from this graduate program to classroom practice. The modeling by two teachers could be possible with the cooperation of co-teachers, a teacher and a teaching assistant, or a teacher and a student. At any point in the year, it is also possible to create small groups to interact as collaborative learning communities and engage in inquiry-based learning.

This book is worth reading for both the practical ideas as well as the discussion of adolescent literacy learning. Aspects of the graduate course and practicum could easily be reproduced by other teacher educators from the detailed descriptions, samples, and vignettes included by the author. Useful to teacher educators are the descriptions of how to foster a collaborative learning community of graduate or undergraduate students. The book includes examples of lesson plans, observation logs and literacy event charts that would be helpful for teacher educators supervising field experiences and practicums. Malavasic guides readers on how to support teachers with strategic teaching, purposeful language choices, and reflection. 
Malavasic made an excellent decision to keep the book under one hundred pages in respect of teachers' and teacher educators' time demands. It is also valuable that the author describes and shows examples of the program and teaching strategies throughout the book. Even in her brevity, the reader is left with enough information to incorporate elements of the program in the classroom. This book is written for readers knowledgeable in teaching and teacher education, and it will add practical and valuable insights for literacy instruction and learning. As teachers of adolescents or teacher educators, the possibility of empowering students to become co-constructors of knowledge in literacy events is well within your reach with this book in hand.

\section{Declaration of Conflicting Interests}

The author declared no potential conflicts of interest with respect to the research, authorship, and/or publication of this article.

\section{Funding}

The authors received no financial support for this research.

\section{References}

Malavasic, J. (2019). Collaborative learning communities in middle school literacy education: Increasing student engagement with authentic literacy. Routledge. https://doi.org/10.4324/9780429425103

Moje, E., Dillon, D., \& O'Brien, D. (2000) Reexamining roles of learner, text, and context in secondary literacy. Journal of Educational Research, 93(3), 165-180. https://doi.org/10.1080/00220670009598705

Mok, J. (2008). Distributed cognition in learning. The International Journal of Learning, 15(4), 151159. https://doi.org/10.18848/1447-9494/CGP/v15i04/45708

Moll, L., Amanti, C., Neff, D., \& Gonzalez, N. (1992). Funds of knowledge for teaching: Using a qualitative approach to connect homes and classrooms. Theory Into Practice, 31(2), 132-141. https://doi.org/10.1080/00405849209543534

Santa, C. (2006). A vision for adolescent literacy: Ours or theirs? Journal of Adolescent \& Adult Literacy, 49(6), 466-476. https://doi.org/10.1598/jaal.49.6.2 